\title{
Comparing undergraduate nursing students' academic engagement and achievement in traditional versus blended learning models
}

\author{
ENAS HASSAN SAAD ${ }^{1}$, MAGDA ABD ALHAMID ABD AL FATTAH ${ }^{2}$, AHMED MAHMOUD FAKHRY ${ }^{3}$, MOHAMMED ALI \\ PESSA 4 \\ ${ }^{1}$ Enas Hassan Saad, Assistant lecturer, Nursing Administration Department, Faculty of Nursing, Cairo University, Egypt \\ ${ }^{2}$ Magda Abd Alhamid Abd Al Fattah, Professor, Nursing Administration Department, Faculty of Nursing, Cairo University, Egypt \\ ${ }^{3}$ Ahmed Mahmoud Fakhry, Assistant Professors, Educational technology, Faculty of educate studies for education, Cairo University, Egypt \\ ${ }^{4}$ Mohammed Ali Pessa, Lecturer, Nursing Administration Department, Faculty of Nursing, Cairo University, Egyp \\ Corresponding author: Enas Hassan Saad, Assistant lecturer, Nursing Administration Department, Faculty of Nursing, Cairo University, \\ Egypt. Email: enashassan2015@gmail.com
}

\begin{abstract}
Background: Nursing education is rapidly accelerating the use of technology as a blended learning environment, which is a form of e-learning, with the technological advancement to improve learning in both clinical and theoretical courses.

Aim: To compare undergraduate nursing students' academic engagement and academic achievement in traditional versus blended learning models.

Design: A quasi-experimental design was utilized in this study.

Setting: This study was conducted in the Faculty of Nursing - Cairo University.

Method: A purposive sample of undergraduate nursing students who were studying a "nursing administration" course. Academic Engagement Questionnaire was used to measure the 'intervention' and control groups of nursing students' academic engagement in nursing administration course". Academic Achievement checklist was used to assess the Grade Point Average (GPA) of the final term exam.

Results: there was no statistical significance difference between intervention and control groups of nursing students regarding academic engagement $(p=0.21)$. In terms of Nursing Students' Academic Achievement levels (GPA), there was a highly statistically significant difference between nursing student intervention and control groups, in which the intervention group of nursing students had the highest mean score $(p=0.0001)$.

Conclusion: the current study concluded that the implementation of the "blended learning model" had a positive impact on students; academic achievement while the academic engagement had no difference.

Keywords: Blended learning model - Traditional lecturing - Academic Engagement Achievement
\end{abstract}

\section{INTRODUCTION}

The pandemic spread of the Novel Corona Virus (COVID19) has created fear, anxiety, and several concerns among people around the world. It has disrupted every aspect of human life including education throughout the globe. The pace of its spread made educational institution closure one of the best preventive measures against it. To mitigate the direct impact of the virus and prevent the students from psychological depression, educational institutions have initiated the momentum of educating the students through different means and modalities based on both human and material resources available in the context (Mertens, Gerritsen, Duijndam, Salemink, and Engelhard, 2020).

In this context, Aborode, Anifowoshe, Ayodele, Iretiayo and David, (2020) state that the virulent disease has made students be reception which has led a numerous institution to arrange a spread of e-learning stages (even though with confronts) to help and confirm that the tutorial schedule runs to closing stages. Technology-based teaching especially online education has become the foremost appropriate alternative to remain educational activities functional in many parts of the world during the pandemic period.

A blended learning environment includes sufficient technology, educators who are properly educated, students who are ready to use technology, and lessons that are adequately prepared. Technology implementation requires time, reflection on the part of educators, and diligent planning to ensure that when integrated learning is infused into the atmosphere of an academic institution. Stakeholders need to consider the uses, advantages, and, most importantly, how the elements of the blended learning model can be used to the greatest possible extent (Kintu, Zhu, and Kagambe, 2017).

Traditional approach of teaching which is concerned with the teacher being the controller of the learning environment, power and responsibility is held by the teachers, and they play the role of instructors and decisionmakers in regards to the content of the curriculum and the outcome of the learning (Srivastava, 2019).

New Teaching strategies reflect the diverse nature of the student population and equip nursing students with the knowledge to be safe and competent, new practitioners who are ready to work' (Afzal and Gilani, 2019). Education is experiencing various kinds of innovation globally, which have helped to transform both human and material resources in the field. This technology has led to different teaching and learning methods in which blended learning is one of the approaches understood as a hybrid of face-toface and technology-mediated teaching types and practices used in teaching and learning. (Williams and Akpan, 2018).

The benefits of both face-to-face methods of learning and online education can be maximized by blended learning. Compared to face-to-face instructions, online instructions rely on extensive use of LMS features and functionalities, enabling goals to be defined effectively, coordinate resources, and encourage engagement and outcomes assessment, while making the interaction 
between student and teacher simpler, more efficient, allowing personalization and significantly overcoming time and space limits (Keržič, Tomaževič, Aristovnik, and Umek, 2019).

Nursing is currently undergoing rapid changes in environments, procedures, and general workforce life. Hospitals are undergoing renovations to work out userfriendly environments. Additionally, care is transitioning to more community-home-based settings, far from hospital settings. the flexibility to use technology to transmit information is critical for these changes. Today's teaching styles involve problem-solving activities, the team (group) learning and tasking, video presentations and on-line learning, case studies, simulation laboratories, active community projects, and much more. The ability to communicate in several ways to and for faculty students assists in their engagement and content retention levels (Pai, 2016).

Engaging students in their learning can be one of the most critical aspects of a successful undergraduate education. Student involvement has been described as a generally recognized measure of the quality of a student's learning experience. Student engagement has many definitions and includes time, effort, resources, participation, activities, emotions, and feelings within the context of embracing student learning. Student engagement could also be a measure for ongoing assessment of the quality of the nursing program and thus the success of graduation students (Hampton and Pearce, 2016).

Internal and external variables influence academic achievement. Internal factors develop active learning capacities, stimulate and use shared teaching habits for students participating in the teaching-learning process. Therefore, teachers should consider their students' motivations and preferred learning styles, track their learning in their academic environment, and encourage them to engage in learning (Nabizadeh, Hajian, Sheikhan and Rafiei 2019), While the external factors that affect the academic achievement of nursing students are extracurricular activities. Extracurricular activities are described as activities that nursing students engage in (Eakman, Kinney, Schierl, \& Henry, 2019).

Blended learning is a global necessity especially in the era of the digital transformation of education. The great advancement in information and communication technology (ICT) made the integration of distance learning with face-toface interaction easier and more effective for teachers and students. Also, the spread of infectious diseases like COVID-19 made the need for a blended model of learning mandatory for school and university students.

So, evaluating and comparing the impact of blended learning and traditional models on nursing students' academic engagement and academic achievement has great importance to educational institutions as it helps them to pinpoint the strengths and to identify areas for improvement, especially in health care teaching institutions.

Thus, piloting the blended learning model along with traditional learning to teach the nursing administration" course to compare the effect of traditional learning and blended learning model on undergraduate nursing student's academic engagement and academic achievement studying nursing administration course.

\section{AIM OF THE STUDY}

The aim of this study was to compare the academic engagement and achievement of undergraduate nursing students in traditional and blended learning models.

Research Hypotheses: H1: The 'intervention' group will get the highest academic engagement mean scores compared to the control group.

H2: The 'intervention' group will get the highest Grade Point Average (GPA) compared to the control group.

Conceptual frameworks: In this study, the theory of Kurt Lewin's Change Management (Kurt Lewin, 1890 - 1947) was adopted. Lewin's change theory identified that change has three stages: the unfreezing stage, the moving stage, and the refreezing stage (Ellis, \&Hartley, 2012)

\section{MATERIALS AND METHODS}

The study used a purposive sample of undergraduate nursing students who were enrolled in a "nursing administration" course at Cairo University's nursing administration department / Faculty of Nursing during a particular semester. The participants in the study were split into two groups: intervention and control. Each group was divided into its own section. The following tools were used to collect data. The first instrument was the "Academic Engagement Questionnaire," which was adapted from Kember \& Leung (2009) to assess nursing students' academic engagement in nursing administration courses in both intervention and control groups.

The second tool "Academic Achievement Checklist" that used to assess the "intervention" and "control" groups of nursing students' Grade Point Average (GPA) of the final term exam 2020. The academic grading scale went goes from "A+" to "F" based on academic regulation 2015/2016.

Procedure: The initial approval to conduct the study was obtained from the research and ethical committee then obtain official permission from the Dean, Vice Dean of Post Graduate Studies and Research, and Vice Dean for Education and Student Affairs at Faculty of Nursing - Cairo University. The procedure was carried out in four phases according to Kurt Lewin's Change Management Theory.

First phase: unfreeze: During this phase, the investigator obtained a list of undergraduate nursing students' names, and the investigator clarified the study's benefits to them in order to persuade them to participate. The investigator then looked at the personal profiles of both the 'intervention' and control groups, as well as the research questionnaires, and validated them. The 'intervention' group of undergraduate nursing students' electronic learning readiness was then measured using an electronic learning readiness questionnaire.

Second phase: moving: During this process, an expert academic team specializing in nursing administration developed the electronic learning strategies based on the approved nursing administration course specification and approved "nursing administration course" book. All of the nursing students were split into two groups. The control group received only face-to-face instruction, while the 'intervention' group received both face-to-face and electronic instruction. 
Third phase refreeze: The academic achievement of nursing students was evaluated in this process at the end of the semester using the (GPA) of the final exam $2019 / 2020$ in the first semester for both the 'intervention' and regulated groups of nursing students (Postintervention).

Ethical consideration: Before conducting the study, the vice Dean for Education and Student Affairs at Cairo University's Faculty of Nursing, as well as the head of the nursing administration department, gave their approval to conduct the proposed study. The study was carried out with the primary approval of the ethical committee. Furthermore, nursing students' permission to participate in the study was formally obtained after a clarification of the study's existence and intent.

Each nursing student was free to participate or not participate in this study, and they had the right to withdraw at any time for any reason. They were also told that, if they do not mind, their data would not be included in any future studies unless they give new consent. The coding of all data ensured the confidentiality and privacy of each subject. Following the collection of data from nursing students, the ethical committee of Cairo University's Faculty of Nursing released a final approval letter stating that all parameters were met.

Statistical design: Upon completion of data collection, the data were scored, tabulated, and analyzed by computer using the "statistical package for the social science" (SPSS), Version 21.00 for analysis. The data were analyzed using descriptive statistics such as frequency mean and standard deviation. Relative statistical test of significance such as (Friedman's ANOVA, independent ttest) were used to identify the relations among the study variables. The $p$ value is the degree of significance, and the significance level of all statistical analysis was at $<0.05(\mathrm{P}$ value) while, the $p$ value $>0.05$ indicates non-significant result.

\section{RESULTS}

Table (1) revealed that the majority $(93.4 \%)$ of intervention and more than half $(54.9 \%)$ of control groups of nursing students were in the $4^{\text {th }}$ academic level. More than half $(54.9 \%)$ of intervention and less than half $(35.2 \%)$ of control groups of nursing students age is 21 years old. Also, a majority (70.3\%) of intervention and more than half $(57.7 \%)$ of control groups of nursing students were female.

Furthermore, a majority of both groups intervention and control groups of nursing students were single $(80.1 \%$, $93.0 \%$ ). A majority of both groups intervention and control groups of nursing students were newly enrolled in this academic year $(96.7 \%, 91.5 \%)$. Well, a majority of both groups intervention and control groups of nursing students had a general secondary degree $(86.8 \%, 83.1 \%)$ respectively as the previous certification.

In addition, a majority (89.0\%) of intervention and about two-third $(64.8 \%)$ of control groups of nursing students had registered 18 credit hours. Moreover, a majority of both groups intervention and control groups of nursing students were unemployed during the study period (84.6\%, $78.9 \%)$. Then, a majority $(79.1 \%)$ of intervention groups of nursing students had previous experience in web-based or online learning and about half $(50.7 \%)$ of the control group of nursing students hadn't previous experience in web-based or online learning. Meanwhile, less than half $(47.3 \%)$ and more than half $(56.3 \%)$ of the control group of nursing students had a smartphone.

Table (1) Personal data of intervention and control groups of nursing students

\begin{tabular}{|c|c|c|c|c|}
\hline \multirow[t]{2}{*}{ Personal data } & \multicolumn{2}{|c|}{$\begin{array}{l}\text { Intervention group } \\
(\mathrm{N}=91)\end{array}$} & \multicolumn{2}{|c|}{$\begin{array}{l}\text { Control } \\
(\mathrm{N}=71)\end{array}$} \\
\hline & No. & $\%$ & No. & $\%$ \\
\hline \multicolumn{5}{|l|}{ Academic level } \\
\hline Second level & 0 & 0.0 & 7 & 9.9 \\
\hline Third level & 6 & 6.6 & 25 & 35.2 \\
\hline Fourth level & 85 & 93.4 & 39 & 54.9 \\
\hline \multicolumn{5}{|l|}{ Age } \\
\hline 20 & 4 & 4.4 & 15 & 21.1 \\
\hline 21 & 50 & 54.9 & 25 & 35.2 \\
\hline 22 & 32 & 35.2 & 19 & 26.8 \\
\hline 23 & 5 & 4.5 & 9 & 12.7 \\
\hline 24 & 0 & 0.0 & 3 & 4.2 \\
\hline \multicolumn{5}{|l|}{ Gender } \\
\hline Male & 27 & 29.7 & 30 & 42.3 \\
\hline Female & 64 & 70.3 & 41 & 57.7 \\
\hline \multicolumn{5}{|l|}{ Marital status } \\
\hline Single & 88 & 80.1 & 66 & 93.0 \\
\hline Married & 3 & 2.73 & 5 & 7.0 \\
\hline \multicolumn{5}{|l|}{ Academic status } \\
\hline New & 88 & 96.7 & 65 & 91.5 \\
\hline Repeater & 3 & 3.3 & 6 & 8.5 \\
\hline \multicolumn{5}{|c|}{ Previous certification } \\
\hline Diploma in nursing & 9 & 9.9 & 8 & 11.3 \\
\hline $\begin{array}{l}\text { Associate degree in } \\
\text { nursing }\end{array}$ & 3 & 3.3 & 4 & 5.6 \\
\hline $\begin{array}{ll}\text { General secondary } \\
\text { degree }\end{array}$ & 79 & 86.8 & 59 & 83.1 \\
\hline \multicolumn{5}{|c|}{ Number of credit hours } \\
\hline 16 & 3 & 3.3 & 19 & 26.8 \\
\hline 17 & 7 & 7.7 & 6 & 8.5 \\
\hline 18 & 81 & 89.0 & 46 & 64.8 \\
\hline \multicolumn{5}{|l|}{ Employment status } \\
\hline None & 77 & 84.6 & 56 & 78.9 \\
\hline Part-time & 9 & 9.9 & 10 & 14.1 \\
\hline Full time & 5 & 5.5 & 5 & 7.0 \\
\hline \multicolumn{5}{|c|}{ Previous experience in web-based or online learning } \\
\hline Yes & 72 & 79.1 & 35 & 49.3 \\
\hline No & 19 & 20.9 & 36 & 50.7 \\
\hline \multicolumn{5}{|c|}{ Communication Device Utilized } \\
\hline Computer & 40 & 44.0 & 21 & 29.6 \\
\hline tablet & 3 & 3.3 & 5 & 7.0 \\
\hline Smartphone & 43 & 47.3 & 40 & 56.3 \\
\hline $\begin{array}{l}\text { Others (ex. } \\
\text { TVsmart } \\
\text { decoders) }\end{array}$ & 5 & 5.5 & 5 & 7.0 \\
\hline
\end{tabular}

Table (2) Academic engagement of intervention and control nursing students group

\begin{tabular}{|l|l|l|l|l|}
\hline $\begin{array}{l}\text { Academic } \\
\text { Engagement }\end{array}$ & $\begin{array}{l}\text { Intervention } \\
\text { group }\end{array}$ & $\begin{array}{l}\text { Control } \\
\text { group }\end{array}$ & \multirow{2}{*}{ t-test } & p-value \\
\cline { 2 - 5 } & $\overline{\bar{x}}+\mathrm{SD}$ & $\overline{\bar{x}}+\mathrm{SD}$ & & \\
\hline $\begin{array}{l}\text { Clinical } \\
\text { engagement }\end{array}$ & $3.69+0.61$ & $3.84+0.56$ & 1.58 & 0.11 \\
\hline $\begin{array}{l}\text { Classroom } \\
\text { engagement }\end{array}$ & $3.69+0.60$ & $3.75+0.63$ & 0.62 & 0.53 \\
\hline $\begin{array}{l}\text { Total academic } \\
\text { engagement }\end{array}$ & $3.69+0.57$ & $3.79+0.48$ & 1.23 & 0.21 \\
\hline
\end{tabular}

*significant at $p$-value $<0.05$ 
Table (2) revealed that there was no statistical significance difference $(\mathrm{t}=1.58, \mathrm{p}=0.11$ ) between intervention and control groups of nursing students regarding clinical engagement. Moreover, there was no statistical significance difference $(t=0.62, p=0.53)$ between intervention and control nursing students group regarding classroom engagement.

Table (3): Achievement levels (GPA) of intervention and control groups of nursing students

\begin{tabular}{|c|c|c|c|c|c|c|c|}
\hline \multirow{2}{*}{$\begin{array}{l}G \\
P \\
A\end{array}$} & \multirow{2}{*}{$\begin{array}{l}\text { Point } \\
\text { number of } \\
\text { GPA }\end{array}$} & \multicolumn{2}{|c|}{$\begin{array}{l}\text { Intervention } \\
\text { Group }(n=91)\end{array}$} & \multicolumn{2}{|c|}{$\begin{array}{l}\text { Control Group } \\
(\mathrm{n}=71)\end{array}$} & \multirow{2}{*}{$\begin{array}{l}\text { Chi- } \\
\text { squa } \\
\text { re }\end{array}$} & \multirow{2}{*}{$\begin{array}{l}\mathrm{p}- \\
\text { value }\end{array}$} \\
\hline & & No. & $\%$ & No. & $\%$ & & \\
\hline A & 3.7 & 4 & 4.4 & 3 & 4.2 & \multirow{7}{*}{28.5} & \multirow{7}{*}{$\begin{array}{l}0.000 \\
1^{*}\end{array}$} \\
\hline$-A$ & 3.4 & 32 & 35.2 & 6 & 8.5 & & \\
\hline $\begin{array}{l}+ \\
\mathrm{B}\end{array}$ & 3 & 28 & 30.8 & 15 & 21.1 & & \\
\hline B & 2.7 & 13 & 14.3 & 16 & 22.5 & & \\
\hline $\begin{array}{l}+ \\
\text { C }\end{array}$ & 2.3 & 7 & 7.7 & 11 & 15.5 & & \\
\hline C & 2 & 4 & 4.4 & 6 & 8.5 & & \\
\hline $\begin{array}{l}+ \\
D\end{array}$ & 1.6 & 3 & 3.3 & 14 & 19.7 & & \\
\hline \multicolumn{2}{|c|}{ Total } & \multicolumn{2}{|c|}{$\begin{array}{l}\bar{x} \pm \mathrm{SD}= \\
2.9 \pm 0.49\end{array}$} & \multicolumn{2}{|c|}{$\begin{array}{l}\bar{x} \pm \text { SD }= \\
2.5 \pm 0.60\end{array}$} & $\begin{array}{l}\mathrm{T}=5 . \\
2\end{array}$ & $\begin{array}{l}0.000 \\
1^{*}\end{array}$ \\
\hline
\end{tabular}

${ }^{*}$ significant at $p$-value $<0.05$

Table (3) indicated that the results of intervention and control groups of nursing students according to their achievement levels (GPA) of final exam of nursing administration course revealed, there was a highly statistically significant difference between intervention and control groups of nursing students regarding their achievement levels (GPA) $(t=5.2, p=0.0001)$, in which; less than half $(35.2 \%)$ of the intervention group had level $(-A)$ level. While less than half $(30.8 \%)$ of the intervention group and less than half $(21.1 \%)$ of the control group had level $(+B)$ level. Moreover, less than half $(22.5 \%)$ of the control group had (B) levels. Furthermore, the lowest percentage $(3.3 \%)$ of the intervention group had $(+D)$ level and the lowest percentage $(4.2 \%)$ of the control group had a $(-A)$ level.

\section{DISCUSSION}

The present study aimed to compare undergraduate nursing student' academic engagement and academic achievement in traditional versus blended learning models

The finding of the present study revealed that the majority of intervention and more than half of control groups of nursing students were in the 4th academic level. More than half of the intervention and less than half of control groups of nursing students age is 21 years old. In addition, a majority of intervention and more than half of control groups of nursing students were female. Furthermore, a majority of both groups intervention and control groups of nursing students were single. A majority of both groups intervention and control groups of nursing students were newly enrolled in this academic year. Well, a majority of both groups intervention and control groups of nursing students had general secondary degree respectively as the previous certification. In addition, a majority of intervention and about two-third of control groups of nursing students had registered 18 credit hours. Moreover, a majority of both groups intervention and control groups of nursing students were unemployed during the study period. Then, a majority of intervention nursing students group had previous experience in web-based or online learning and about half of the control nursing students group hadn't previous experience in web-based or online learning. Meanwhile, less than half and more than half of the control nursing students group had a smartphone.

Concerning the academic engagement, there was no statistically significant difference between the intervention and control group of nursing students regarding clinical engagement. Moreover, there was no statistical significance difference between intervention and control groups of nursing students regarding classroom engagement. This might be because students did not fully understand the course content and therefore did not gain the expected benefits from it. The previous results were in the same line with the study done by Saritepeci and Cakir, (2015) that investigate "The effect of blended learning environments on student motivation and student engagement" stated that Students engagement and subscales of student engagement did not occur significant differences between the intervention group and control group of nursing students in before and after the experiment. This result contradicts the way, Holley \& Dobson (2008), Holley \& Oliver (2010), Chen, Lambert \& Guidry (2010), and Sarıtepeci \& Yıldız (2014) have concluded that blended learning has a positive impact on students' attendance from various angles in their studies performed.

Concerning the achievement levels (GPA) of intervention and control groups, the results of intervention and control groups of nursing students according to their achievement levels (GPA) of final exam of nursing administration course revealed, less than half of the intervention group had level (-A) level, while, only less than tenth control group had level (-A) level. This might reflect the benefits the intervention nursing students group has gained from the program which appeared mostly in their academic achievement. The previous result was in the same line with the study done by Lin, Tseng, \& Chiang, (2016) that investigate "The effect of blended learning in mathematics Course". Stated that using a blended learning approach improved students' achievement scores as compared to other approaches and had improvement effects on students' attitudes toward mathematics. Moreover, Harahap, Nasution, \& Manurung, (2019) that investigate "The effect of blended learning on student's learning achievement and science process skills in plant tissue culture course" concluded that the blended learning strategy found significantly more effective in enhancing students' learning achievement and science process skills in plant tissue culture course as compared to the conventional learning strategy.

\section{CONCLUSION}

The present study aimed to compare undergraduate nursing student' academic engagement and academic achievement in traditional versus blended learning models 
Overall, the study concluded that educating nursing students by using of blended learning model in nursing administration course for nursing students in the intervention group improved their achievement levels (GPA) compared to the control participants. While, less than half the percentage of nursing students with high elearning readiness in the intervention group their academic achievement (GPA) was (-A) level, followed by (+B) level. Furthermore, no statistically significant difference was found between intervention and control groups regarding academic engagement.

Source of Support: Self

Conflict of Interest: None

\section{REFERENCES}

1. Mertens, G., Gerritsen, L., Duijndam, S., Salemink, E., \& Engelhard, I. M. (2020). Fear of the coronavirus (COVID-19): Predictors in an online study conducted in March 2020. Journal of Anxiety Disorders, 74, 102258.

2. Aborode, A., Anifowoshe, O., Ayodele, T. I., Iretiayo, A. R., \& David, O. O. (2020). Impact of COVID-19 on education in sub-saharan Africa.

3. Kintu, M. J., Zhu, C., \& Kagambe, E. (2017). Blended learning effectiveness: the relationship between student characteristics, design features, and outcomes. International Journal of Educational Technology in Higher Education, 14(1), 7.

4. Srivastava, P. (2019). Advantages \& Disadvantages of EEducation \& E-Learning. Journal of Retail Marketing \& Distribution Management, 2(3), 22-27.

5. Afzal, N. F. M. H. M., \& Gilani, M. A. (2019). Nursing Students Challenges at Educational and Clinical Environment. Nursing, 62.

6. Williams, C., \& Akpan, K. P. (2018). Collaborative Versus Contextual Learning and Students' Academic Achievement in Biology. IOSR Journal of Research and Method in Education, 7(6), 6-10.

7. Keržič, D., Tomaževič, N., Aristovnik, A., \& Umek, L. (2019). Exploring critical factors of the perceived usefulness of blended learning for higher education students. PloS one, 14(11), e0223767.

8. Pai, H.-C. (2016) An Integrated Model for the Effects of SelfReflection and Clinical Experience Learning on Clinical Nursing Performance in Nursing Students: A Longitudinal Study. Nurse Educator Today, 45, 156-162.
9. Hampton, D. and Pearce, P.F. (2016) Student Engagement in Online Learning Nursing Courses. Nurse Educator, 41, 294298.

10. Nabizadeh, S., Hajian $S^{*}$, Sheikhan $Z$ and Nabizadeh F. (2019). Prediction of academic achievement based on learning strategies and outcome expectations among medical students BMC Medical Education 19:99 https://doi.org/10.1186/s12909-019-1527-9.

11. Eakman, A. M., Kinney, A. R., Schierl, M. L., \& Henry, K. L. (2019). Academic performance in student service members/ veterans: Effects of instructor autonomy support, academic self-efficacy, and academic problems.

12. Lippitt, R. (1947). Kurt Lewin, 1890-1947. Adventures in the exploration of interdependence.

13. Ellis JR, Hartley CL (2012): Nursing in today's world: challenges, issues, and trends, ed 10, Philadelphia, Wolters Kluwer/ Lippincott Williams \& Wilkins.

14. Saritepeci, M., \& Cakir, H. (2015). The effect of blended learning environments on student motivation and student engagement: A study on social studies course. Egitim ve Bilim, 40(177).

15. Holley, D., \& Dobson, C. (2008). Encouraging student engagement in a blended learning environment: The use of contemporary learning spaces. Learning, Media and Technology, 33(2), 139-150.

16. Holley, D., \& Oliver, M. (2010). Student engagement and blended learning: Portraits of risk. Computers \& Education, 54(3), 693-700.

17. Chen, D. P., Lambert, D. A., \& Guidry, R. K. (2010). Engaging online learners: The impact of web-based learning technology on college student engagement. Computers ve Education. 54(4), 1222-1232.

18. Sarıtepeci, M., \& Yıldız, H. (2014). Harmanlanmış öğrenme ortamlarının öğrencilerin derse katılım ve derse karşı motivasyonları üzerine etkisinin incelenmesi. Kırşehir Eğitim Fakültesi Dergisi (KEFAD), 35(1), 115-129.

19. Lin, Y. W., Tseng, C. L., \& Chiang, P. J. (2016). The effect of blended learning in a mathematics course. EURASIA Journal of Mathematics, Science and Technology Education, 13(3), 741-770.

20. Harahap, F., Nasution, N. E. A., \& Manurung, B. (2019). The Effect of Blended Learning on Student's Learning Achievement and Science Process Skills in Plant Tissue Culture Course. International Journal of Instruction, 12(1), 521-538. 